\title{
FUNCTIONAL SIGNIFICANCE OF IDIOPATHIC ADRENAL CALCIFICATION IN THE ADULT
}

\author{
R. D. HOELDTKE, R. A. DONALD, AND M. G. NICHOLLS \\ The Divisions of Endocrinology and Metabolism, and Hypertension, Department of \\ Internal Medicine, University of Michigan, Ann Arbor, Michigan and The Medical \\ Unit, Princess Margaret Hospital, Christchurch, New Zealand
}

(Received 13 August 1979; accepted 12 September 1979)

\begin{abstract}
SUMMARY
Two young adults with idiopathic adrenal calcification are described. In one patient the calcification was probably secondary to adrenal haemorrhage in the neonatal period. Neither patient exhibited clinical features suggestive of adrenal cortical insufficiency, and baseline serum cortisol levels were normal. The corticosteroid responses to $\mathrm{ACTH}$ administration and to other provocative tests indicated that both glucocorticoid and mineralocorticoid reserve was normal. One patient showed an appropriate epinephrine response to insulininduced hypoglycaemia. We conclude that even extensive adrenal calcification may be compatible with completely normal adrenal function. Since, however, little is known of the natural history of this condition, lifelong follow-up of such patients is advised.
\end{abstract}

A wide variety of disease entities in addition to tuberculosis and other granulomatous disea ses can cause calcification of the adrenal glands. Neuroblastomas (McAfee \& Balli, 1956) and familial xanthomatosis (Wolman et al., 1961) are commonly associated with adrenal calcification. Such calcification is less frequently seen in Niemann Pick's disease (Alexander, 1946) and has been described in Cushing's syndrome (Price \& Farmer, 1969), phaeochromocytoma (Snyder \& Vick, 1947), and cytomegalovirus infections (Magnin, 1973). In addition, adrenal cysts (Wagner, 1961) or adenomas (Epstein et al., 1973) may calcify. There is considerable evidence for an association between obstetrical trauma, adrenal haemorrhage and subsequent adrenal calcification in the paediatric literature (Snelling \& Erb, 1935; Jarvis \& Seaman, 1959; Black \& Williams, 1973; Newman et al., 1979), but this problem has received little attention in the endocrine literature pertaining to adults.

In the present report we describe two young men in whom adrenal calcification was discovered as an incidental finding. In one patient the adrenal calcification was probably secondary to obstetric trauma and subsequent haemorrhage into the adrenal; in the other

Correspondence: Dr R. D. Hoeldtke, Division of Endocrinology and Metabolism, Box 2, C 7009 Outpatient Building, University of Michigan Medical Center, Ann Arbor, Michigan 48109, USA.

0300-0664/80/0400-0319\$02.00 (C) 1980 Blackwell Scientific Publications 
patient the cause of the adrenal calcification was not determined. These patients exhibited no clinical evidence of adrenal insufficiency. Detailed biochemical evaluation of all aspects of adrenal function failed to reveal any abnormalities, although both patients had borderline elevations of their ACTH levels.

\section{CASE REPORTS}

\section{Patient 1}

This 29-year-old white male was in good health until August 1978, when he developed the gradual onset of lethargy, fatigue and malaise. There was no anorexia, weight loss, fever or cough. Upon seeking medical advice, the patient was found to be hypertensive (blood pressure 150/100 right arm sitting) and an intravenous pyelogram was performed. Plain films of the abdomen revealed striking bilateral adrenal calcification (Fig. 1). On physical examination there was no hyperpigmentation, evidence of dehydration or postural hypotension. Electrolytes, blood sugar and blood urea nitrogen were normal. There was no history of tuberculosis, and PPD (intermediate strength) skin tests were negative on repeated testing. Delayed hypersensitivity responses to Candida antigen were positive. Complement fixation tests for coccidiomycosis, histoplasmosis and blastomycosis were negative. Serological screening tests for echinococcus and toxoplasmosis were also negative. The chest X-ray was within normal limits. A rapid sequence intravenous pyelogram was normal. A family history revealed that the patient's father was also mildly hypertensive.
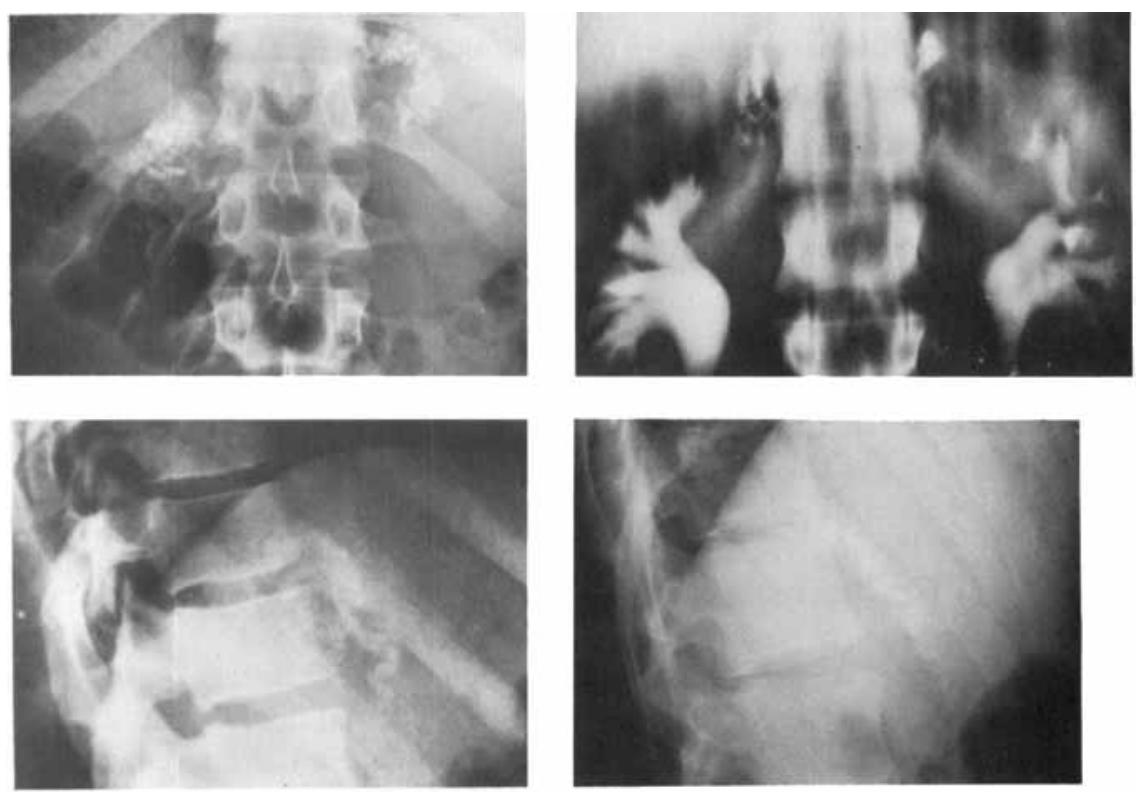

Fig. 1. The X-ray appearance of adrenal calcification in two adult males. Both antero-posterior and lateral films are shown for patient 1 (left) and patient 2 (right). The film for patient 2 was obtained during intravenous pyelography. 
Review of past medical history revealed that the patient was born at 34 weeks, weighing 3 pounds, 14 ounces. The third stage of labour was prolonged and the patient's twin brother suffered irreversible, severe brain damage as a result.

He was admitted to the University of Michigan Clinical Research Centre for endocrine evaluation in January 1979. At that time he was on no antihypertensive therapy or other medication.

\section{Patient 2}

This 23-year-old American soldier, stationed in Malaysia in 1971, was discovered to have adrenal calcification during evaluation of an injury to his back (Fig. 1). The patient had no signs or symptoms of adrenal insufficiency or hypercortisolism and was in a state of excellent general health. The patient had no history of anorexia, fever or weight loss and his physical examination was completely normal. There were no pulmonary complaints or history of tuberculosis exposure, and the chest X-ray was normal. Birth history was not available. The patient had been given BCG immunization in 1968 before leaving for Malaysia, so a tuberculin skin test was not performed. Urine cultures for acid fast bacilli were negative on three occasions. Blood urea nitrogen, electrolytes, blood sugar, liver function tests and complete blood counts were all normal.

The patient was admitted in 1971 to Princess Margaret Hospital, Christchurch, New Zealand, for evaluation of adrenal cortical function.

\section{METHODS}

\section{Patient 1}

Plasma cortisol (Dash et al., 1975), ACTH (Vague et al., 1971), plasma renin activity (Haber et al.,1969), angiotensin II (Nicholls \& Espiner, 1976) and aldosterone in urine (Bayard et al., 1970) and plasma (Antunes et al., 1976) were méasured by radioimmunoassay. Plasma epinephrine was assayed by a single isotope radioenzymatic method (Peuler \& Johnson, 1977).

\section{Patient 2}

Plasma cortisol was measured by a fluorometric method (De Moor et al., 1960) and ACTH by radioimmunoassay (Donald, 1968).

\section{RESULTS}

\section{Patient I}

Cortisol levels at $09.00 \mathrm{~h}$ ranged between 20 and $24 \mu \mathrm{g} / \mathrm{dl}$ (normal range $7-27 \mu \mathrm{g} / \mathrm{dl}$ ), and supine plasma aldosterone $(10 \mathrm{mEq} /$ day sodium diet) on separate determinations were $21 \cdot 1$ and $36 \cdot 1 \mathrm{ng} / \mathrm{dl}$ (normal range $17-33 \mathrm{ng} / \mathrm{dl}$ ). Both cortisol and aldosterone levels rose briskly following the intravenous administration of Cortrosyn ${ }^{\circledR} 0.25 \mathrm{mg}$ (Table 1 ). Plasma ACTH at $09.00 \mathrm{~h}$ was $95.1 \mathrm{pg} / \mathrm{ml}$ (normal range $35-95 \mathrm{pg} / \mathrm{ml}$ ). Plasma renin activity, angiotensin II and plasma aldosterone levels all increased rapidly after the ingestion of a $10 \mathrm{mEq}$ sodium diet combined with upright posture (Table 2). The observed levels of angiotensin II and aldosterone were within normal limits, but plasma renin 
Table 1. Cortisol and aldosterone response to ACTH stimulation*

\begin{tabular}{ccccc}
\hline & \multicolumn{3}{c}{ Patient l } & Patient 2 \\
\cline { 2 - 3 } $\begin{array}{c}\text { Minutes after } \\
\begin{array}{c}0.25 \text { mg Cortrosyn } \\
\text { i.v. }\end{array}\end{array}$ & $\begin{array}{c}\text { Serum cortisol } \\
(\mu \mathrm{g} / \mathrm{dl})\end{array}$ & $\begin{array}{c}\text { Plasma aldosterone } \\
(\mathrm{ng} / \mathrm{dl})\end{array}$ & $\begin{array}{c}\text { Serum cortisol } \\
(\mu \mathrm{g} / \mathrm{dl})\end{array}$ \\
\hline 0 & 23.7 & $36 \cdot \mathrm{l}$ & 7.0 \\
30 & 32.6 & 58.4 & \\
60 & 37.8 & 61.8 & 27.4 \\
120 & 38.1 & 40.9 & \\
\hline
\end{tabular}

* In patient 1 ACTH was administered intravenously as a bolus, and in patient 2 was given as an intramuscular injection. Patient 1 was studied while receiving a low sodium diet ( $10 \mathrm{mEq} /$ day).

activity was higher than expected (Table 2). Following the administration of intravenous insulin $(0.15$ unit $/ \mathrm{kg})$ the patient's blood glucose dropped to $19 \mathrm{mg} / \mathrm{dl}$ and an appropriate rise in circulating epinephrine and cortisol resulted (Fig. 2).

The patient was discharged from the hospital on no therapy with the diagnoses of idiopathic adrenal calcification and mild essential hypertension. His presenting symptoms of lethargy, fatigue and malaise were transient and no underlying cause was found.

Table 2. The effect of dietary sodium intake and upright posture on the renin-angiotensin system in patient 1

\begin{tabular}{|c|c|c|}
\hline & $160 \mathrm{mEq} \mathrm{Na}$ Diet & $10 \mathrm{mEq} \mathrm{Na}$ Diet \\
\hline \multicolumn{3}{|l|}{ Plasma renin activity } \\
\hline $08.00 \mathrm{~h}$ supine & $\begin{array}{c}3.79 \mathrm{ng} / \mathrm{ml} / \mathrm{h} \\
(0-1.6)\end{array}$ & $\begin{array}{c}6.77 \mathrm{ng} / \mathrm{ml} / \mathrm{h} \\
(1.5-7.9)\end{array}$ \\
\hline $10.00 \mathrm{~h}$ upright & $\begin{array}{c}9.90 \mathrm{ng} / \mathrm{ml} / \mathrm{h} \\
(0.3-3.4)\end{array}$ & $\begin{array}{c}29 \cdot 71 \mathrm{ng} / \mathrm{ml} / \mathrm{h} \\
(3 \cdot 3-15 \cdot 5)\end{array}$ \\
\hline \multicolumn{3}{|l|}{ Serum angiotensin II } \\
\hline $08.00 \mathrm{~h}$ supine & $\begin{array}{c}9.0 \mathrm{pg} / \mathrm{ml} \\
(8-25)\end{array}$ & $\begin{array}{c}42.0 \mathrm{pg} / \mathrm{ml} \\
(18-55)\end{array}$ \\
\hline $10.00 \mathrm{~h}$ upright & $\begin{array}{l}57.0 \mathrm{pg} / \mathrm{ml} \\
(15-50)\end{array}$ & $\begin{array}{c}113.0 \mathrm{pg} / \mathrm{ml} \\
(35-115)\end{array}$ \\
\hline \multicolumn{3}{|l|}{ Plasma aldosterone } \\
\hline $08.00 \mathrm{~h}$ supine & $\begin{array}{l}16 \cdot 2 \mathrm{ng} / \mathrm{dl} \\
(6 \cdot 5-17 \cdot 5)\end{array}$ & $\begin{array}{c}21 \cdot 1 \mathrm{ng} / \mathrm{dl} \\
(17-33)\end{array}$ \\
\hline $10.00 \mathrm{~h}$ upright & $\begin{array}{c}25 \cdot 4 \mathrm{ng} / \mathrm{dl} \\
(11-27)\end{array}$ & $\begin{array}{c}79 \cdot 7 \mathrm{ng} / \mathrm{dl} \\
(40-90)\end{array}$ \\
\hline Urinary aldosterone $/ 24 \mathrm{~h}$ & $\begin{array}{l}10 \cdot 3 \mu \mathrm{g} \\
(5-12)\end{array}$ & $\begin{array}{l}26.9 \mu \mathrm{g} \\
(10-25)\end{array}$ \\
\hline
\end{tabular}

The results were obtained on the fourth day of both diets. The numbers in parentheses represent the normal ranges under the stated experimental conditions. For plasma renin activity and plasma aldosterone this range includes two standard deviations from the mean. 

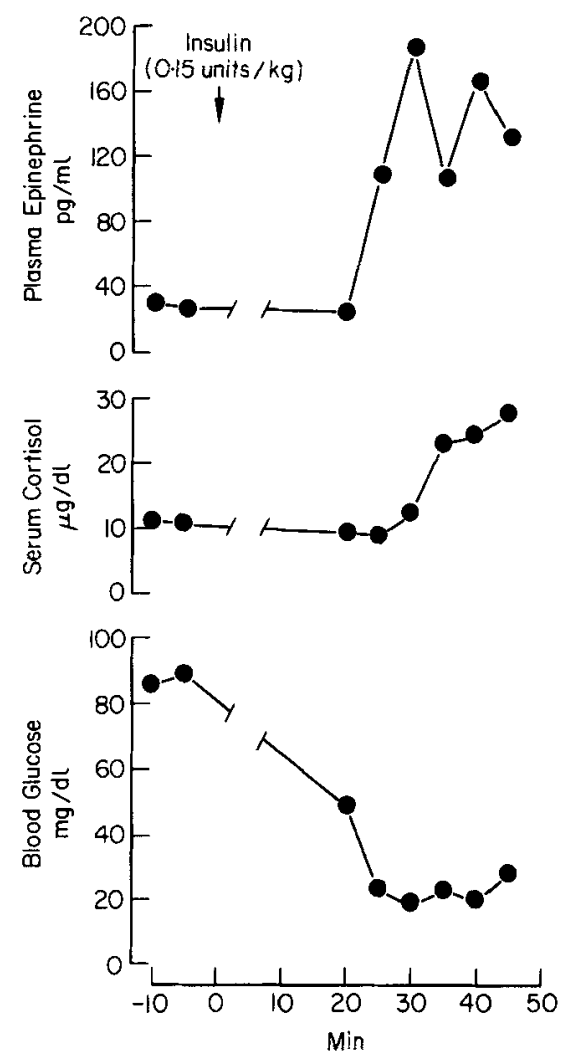

Fig. 2. Epinephrine, cortisol and glucose responses to insulin $(0 \cdot 15 \mathrm{u} / \mathrm{kg}$ regular insulin) given as a single intravenous bolus in patient 1 . After baseline sampling, no blood was drawn until 20 min after insulin administration (discontinuous line).

\section{Patient 2}

Cortisol levels drawn at $08.00 \mathrm{~h}$ ranged between 7 and $12 \mu \mathrm{g} / \mathrm{dl}$ (normal range 7-20 $\mu \mathrm{g} / \mathrm{dl}$ ) and rose briskly following Cortrosyn ${ }^{\otimes 0} 0.25 \mathrm{IM}$ (Table 1). Plasma ACTH at $08.00 \mathrm{~h}$ on two separate determinations was $100 \mathrm{pg} / \mathrm{ml}$ and $123 \mathrm{pg} / \mathrm{ml}$ (normal range 5-95). Cortisol secretion rate was $30 \mathrm{mg} / 24 \mathrm{~h}$ (normal range $12-30 \mathrm{mg} / 24 \mathrm{~h}$ ). Aldosterone secretion was tested indirectly by measuring the urine and serum electrolyte responses to severe sodium restriction. On the fifth day of a $10 \mathrm{mEq} /$ day sodium and $60 \mathrm{mEq} /$ day potassium diet, urinary sodium excretion was $9.5 \mathrm{mEq} / 24 \mathrm{~h}$ and potassium excretion was $75.6 \mathrm{mEq} / 24 \mathrm{~h}$. Serum sodium at that time was $137 \mathrm{mEq} / \mathrm{l}$ and potassium was $4.25 \mathrm{mEq} / \mathrm{l}$.

\section{DISCUSSION}

Numerous children with idiopathic adrenal calcification have been described (Jarvis \& Seaman, 1959; Black \& Williams, 1973) and only rarely do these patients exhibit clinical features of adrenal cortisol insufficiency. Many of the cases, however, were reported prior to the development of sensitive assay procedures, so adrenal reserve could not be fully assessed. Our two patients were studied in order to see whether their adrenal calcification 
was associated with subtle or subclinical adrenal insufficiency. This consideration is of practical importance, since it is possible that these patients may be at risk of developing adrenal insufficiency under stressful circumstances such as surgery, major trauma or severe illness. Such patients with adrenal calcification may be at risk from developing adrenal insufficiency in adulthood, even though the vast majority of them apparently do not do so as children (Jarvis \& Seaman, 1959).

Present data indicate that our two patients had normal mineralocorticoid and glucocorticoid levels and adequate adrenocortical reserve. For patient 1 , aldosterone levels in plasma and urine were normal and they responded appropriately to sodium restriction, postural change and ACTH (Tables 1 and 2). Whereas the elevated plasma renin values in this patient might be taken to indicate early mineralocorticoid deficiency, concomitant angiotensin II levels were within normal limits, and as noted aldosterone responsiveness to sodium restriction and to ACTH stimulation were brisk, indicating normal aldosterone reserve. The reason for the raised plasma renin levels is not readily apparent. Patient 2 was studied prior to the widespread availability of aldosterone radioimmunoassays, but his ability to conserve urinary sodium and maintain normal serum electrolytes on a sodium restricted diet strongly suggests normal aldosterone reserve. His cortisol secretion rate was $30 \mathrm{mg} / 24 \mathrm{~h}$, and both patients had normal serum cortisol levels as well as brisk cortisol responses to ACTH (Table 1). In addition, the cortisol increment during hypoglycaemic stimulation was normal in patient 1 .

Another young adult with non-tuberculous adrenal calcification and a history of birth trauma has recently been described, and this patient's cortisol rise following ACTH administration was also normal (Cohen et al., 1978). The borderline elevation of ACTH in our two patients is thus the only indication of a possible disorder of glucocorticoid secretion resulting from their adrenal calcification. Only long-term follow-up will determine whether or not their mild elevations of ACTH are indicative of a propensity to the eventual development of glucocorticoid insufficiency.

Studies of adrenal medullary function were performed on patient 1 since, in children, adrenal calcification has been associated with defective epinephrine responses to insulininduced hypoglycaemia (Jacobsen et al., 1975; Ploier et al., 1978). These latter patients were reported to have normal adrenal cortical function. Patient 1 had no history of hypoglycaemia and his epinephrine response to insulin-induced hypoglycaemia was vigorous (Fig. 2).

\section{ACK NOWLEDGMENTS}

We are grateful to Dr R. J. Grekin for the assay of serum aldosterone, and to Judy Mertens for typing the manuscript. Patient 1 was studied in the Clinical Research Centre, University of Michigan Medical School, under a grant from the USPHS, No. 5-MO1-RR-42. Dr Hoeldtke was supported, in part, by USPHS T32 AMO7245.

\section{'REFERENCES}

ALEXANDER, W.S. (1946) Niemann-Pick disease; report of case showing calcification in adrenal glands. New Zealand Medical Journal, 45, 43-45.

ANTUNES, J.R., DALE, S.L.\& MELBY, J.C. (1976) Simplified radioimmunoassay for aldosterone- $\gamma$-lactone. Steroids, 28, 621-630.

BAYARD, F., BEITINS, I.Z., KOWARSKI, A. \& MIGEON, C.J. (1970) Measurement of aldosterone secretion rate by radioimmunoassay. Journal of Clinical Endocrinology, 31, 507-510. 
BLACK, J. \& WILLIAMS, D.I. (1973) Natural history of adrenal haemorrhage in the newborn. Archives of Diseases in Childhood, 48, 183-190.

COHEN, K.L., HARRIS. S. \& KEOHANE, M. (1978) Upper abdominal calcification in a young man. Journal of the American Medical Association, 240, 1639-1640.

DASH, R.J., ENGLAND, B.G., MIDGLEY, A.R. \& NISWENDER G.D. (1975) A specific, non-chromatographic radioimmunoassay for human plasma cortisol. Steroids, 26, 647-661.

DE MOOR, P., RASKIN, B. \& STEENO, O. (1960) Fluorimetric determination of free plasmatic and urinary 4,3-keto-11-hydrocorticoids. Annals of Endocrinology, 21, 479-494

DONALD, R.A. (1968) Application of the coated charcoal separation method to the radioimmunoassay of plasma corticotrophin. Journal of Endocrinology, 41, 499-508.

EPSTEIN, S., MCLAREN, E.H. \& GOLDIN, A.R. (1973) Anomalous responses to stimulation and suppression tests in Cushing's syndrome due to a calcified adrenal adenoma. Postgraduate Medical Journal, 49, 923-926.

HABER, E., KOERNER, T, PAGE, L.B., KLIMAN, B. \& PURNODE, A. (1969) Application of a radioimmunoassay for angiotensin $I$ to the physiologic measurement of plasma renin activity in normal human subjects. Journal of Clinical Endocrinology, 29, 1349-1355.

JACOBSEN, B.B., KASTRUP, K.W. \& CHRISTENSEN, N.J. (1975) Plasma adrenalin in a child with ketotic hypoglycemia and calcifications of the suprarenal glands. Acta Paediatrica Scandinavica, 64, 559-561 .

JARVIS, J.L. \& SEAMAN, W.B. (1959) ldiopathic adrenal calcification in infants and children. American Journal of Roentgenology, 82, 510-520.

MAGNIN, D. (1973) Calcification of the adrenal gland and cytomegalovirus infection in early childhood. Helvetica Paediatrica, 28, 135-143.

MCAFEE, J.G.\& BALLI, C.E. (1956) Radiological diagnosis of diseases of adrenal origin. American Journal of Medical Science, 232, 572-599.

NEWMAN, S.L., PAPCIAK, M.R. \& GAY, B.B. (1979) Adrenal calcification present at birth. Southern Medical Journal, 72, 372-373.

NICHOLLS, M.G. \& ESPINER, E.A. (1976) A sensitive rapid radioimmunoassay for angiotensin II. Nen' Zealand Medical Journal, 83, 399-403.

PEULER, J.D. \& JOHNSON, G.A. (1977) Simultaneous single isotope radioenzymatic assay of plasma norepinephrine, epinephrine and dopamine. Life Sciences, 21, 625-636.

PLOIER, R., TULZER, W., ZIMPRICH, H. \& PARTH, K. (1978) Endocrinological aspects of ketotic hypoglycemia and adrenal calcification. Klinische Paediatrie, 190, 313-318.

PRICE, W.F.\& FARMER, T.A. (1969) Cushing's syndrome and adrenal medullary insufficiency with bilateral adrenal calcification. Journal of Clinical Endocrinology, 29, 368-373.

SNELLING, C.E. \& ERB, I.H. (1935) Haemorrhage and subsequent calcification of the suprarenal. Journal of Pediatrics, 6, 22-41.

SNYDER, C.H. \& VICK, E.G. (1947) Hypertension in children caused by pheochromocytoma; report of three cases and review of literature. American Journal of Diseases of Children, 73, 581-601.

VAGUE, P., OLIVER, C., JAQUET, P. \& VAGUE, J. (1971) Le dosage radioimmunologique de l'ACTH plasmatique. Resultats chez les sujets normaux. European Journal of Clinical and Biological Research, 16, 485-493.

WAGNER, A.C. (1961) Bilateral hemorrhagic pseudocysts of the adrenal gland in a newborn. American Journal of Roentgenology, 86, 540-544.

WOLMAN, M., STERK, V.V., GRATT, S. \& FRENKEL, M. (1961) Primary familial xanthomatosis with involvement and calcification of adrenal. Pediatrics, 28, 742-757. 
